\title{
Synthesis of Some Oxazine Compounds Derived from TDI and Schiff Bases
}

\section{Ghufran T Sadeek, Mohammad S Al-Ajely* and Neam H Saleem}

Chemistry Department, College of Education for Girls, College of Education for Pure Science, Mosul, Iraq

*Corresponding Author: Mohamed S AL-Ajely, Chemistry Department, College of Education for Girls, College of Education for Pure Science, Mosul, Iraq.
Received: August 05, 2020

Published: August 31, 2020

C All rights are reserved by Mohamed S

AL-Ajely., et al.

\section{Abstract}

It is known from ongoing research on heterocyclic compounds that these compounds are used as drug and drug carriers, According to FDI reports that these compounds forms $90 \%$ drug for cancer and 75\% drugs for different diseases. It was also known from our studies on oxazine compounds that this type of heterocyclic compounds had versatile application in medicine. In this study, new 3,1-Benzoxazine compounds (S7-12) were prepared by cyclization reaction of some 2-(benzylidene-amino) benzoic acids (S1-6) with Toluene diisocyanate (TDI) under reflex conditions in chloroform. The structure of the synthesized compounds were confirmed by IR, 1HNMR spectral studies.

Keywords: Oxazine Compounds; Insects; Fungi; 1HNMR

\section{Introduction}

It is well established that Oxazine compounds are quite useful and effective in pharmaceutical and other medical areas, These compounds prove to have anti-bacterial [1,2], anti-plasmodia [3], anti-cancer [4], anti-depressant [5], ant-toxicity [6], and anti-neoplastic effects [7]. The oxazine compounds are considered to be a significant type of heterocyclic compounds toward drug and drug discovery programs. The first time that the oxazine compounds were synthesized was in the year of 1944 by Holly and Cope using the traditional Mannich condensation of phenol, formaldehyde and amines [8]. Other researchers are currently interested in the synthesis using other methods such as solvent-free synthesis [9-11], hetero Diels-alder reaction [12], Some researchers have used induced condensation reaction for the synthetic reaction of this type of compounds $[13,14]$ and cyclization reaction with chalcones [2]. Many vital and significant factors, such as reactant structures, sol- vent-effect [15], reaction temperature [16], and reaction duration time [17] play a decisive role in the synthesis process and have an impact on the properties of these types of compounds. Moreover, all the previous studies of this type of compounds are very valuable in the chemistry of natural products owing to the formation of acetal-glycoside in a plant [18], which acts as a plant's own factor of resistance against insects, pests, fungi and microbic diseases [19]. In accordance with the above-mentioned importance of this type of compounds, we have chosen, for this research, cyclization reaction as a method of preparation new oxazine derivatives from Schiff bases and isocyanates for the synthesis of series of these new oxazine compounds in our drug discovery program.

\section{Experimental}

All melting points were uncorrected using thermal SMP30 UK melting point apparatus. IR spectra were recorded using Alpha 


\begin{tabular}{|c|c|c|c|c|c|c|}
\hline $\begin{array}{c}\text { Comp. } \\
\text { No. }\end{array}$ & Ar. & $\begin{array}{c}\text { Molecular } \\
\text { Formula }\end{array}$ & $\begin{array}{c}\text { M.Wt } \\
\text { gm/mol }\end{array}$ & $\begin{array}{c}\text { M.P. } \\
\text { (C) }\end{array}$ & $\begin{array}{c}\text { Yield } \\
\%\end{array}$ & Colour \\
\hline & $\mathrm{C}_{14} \mathrm{H}_{10} \mathrm{BrNO}_{2}$ & 304 & $95-97$ & 75 & Brown \\
\hline $\mathrm{S}_{2}$ & $\mathrm{C}_{12} \mathrm{H}_{9} \mathrm{NO}_{2}$ & 215 & $142-144$ & 93 & purple \\
\hline $\mathrm{S}_{4}$ & $\mathrm{C}_{2}$ & $\mathrm{C}_{14} \mathrm{H}_{10} \mathrm{ClNO}_{2}$ & 259 & $75-77$ & 96 & Brown \\
\hline $\mathrm{S}_{5}$ & $\mathrm{C}_{14} \mathrm{H}_{10} \mathrm{~N}_{2} \mathrm{O}_{4}$ & 270 & $131-132$ & 96 & Brown \\
\hline $\mathrm{S}_{6}$ & $\mathrm{C}_{14} \mathrm{H}_{11} \mathrm{NO}_{2}$ & 225 & $67-68$ & 97 & purple \\
\hline
\end{tabular}

Table 1: Physical properties of compounds $\left(\mathrm{s}_{1-6}\right)$.

(ATR) instrument. ${ }^{1} \mathrm{HNMR}$ spectra were recorded using Varian Agilent 499.53MHZ instrument, DMSO as internal solvent. All chemical were supplied by sigma -Aldrich, BHD and Fluka companies.

General procedure for the synthesis of 2-carboxy arylidine aniline $\left(\mathbf{s}_{1-6}\right)[20]$

A mixture of ( $1 \mathrm{mmol})$ of an anthranilic acid and (1.2 mmol) of an aryl aldeyde in methanol was stirred for about $1 \mathrm{~h}$. at room temperature. The solvent was removed under reduced pressure to give crude product which was washed with n-hexane and recrystallized from ethanol to afford the Schiff bases $\left(\mathrm{S}_{1-6}\right)$ as pure compounds. Physical properties were listed in table 1.

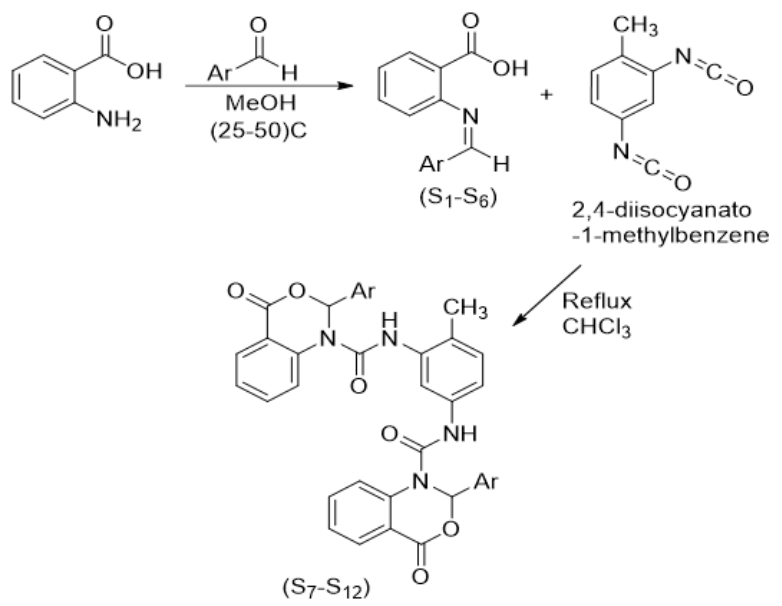

Scheme 1: The synthetic pathway for the synthesis of compounds (S1-12). 


\begin{tabular}{|c|c|c|c|c|c|c|}
\hline $\begin{array}{c}\text { Comp. } \\
\text { No. }\end{array}$ & Ar. & $\begin{array}{c}\text { Molecular } \\
\text { Formula }\end{array}$ & $\begin{array}{c}\text { M.Wt } \\
\text { gm/mol }\end{array}$ & $\begin{array}{c}\text { M.P. } \\
\text { ('C) }\end{array}$ & $\begin{array}{c}\text { Yield } \\
\text { \% }\end{array}$ & Color \\
\hline $\mathrm{S}_{7}$ & $\mathrm{C}_{37} \mathrm{H}_{26} \mathrm{Br}_{2} \mathrm{~N}_{4} \mathrm{O}_{6}$ & 782.5 & 219 dec. & 65 & white \\
\hline $\mathrm{S}_{8}$ & $\mathrm{C}_{37}$ & $\mathrm{C}_{33} \mathrm{H}_{26} \mathrm{~N}_{6} \mathrm{O}_{10}$ & 714.6 & $258-260$ & 97 & yellow \\
\hline $\mathrm{S}_{10}$ & & $\mathrm{C}_{33} \mathrm{H}_{24} \mathrm{~N}_{4} \mathrm{O}_{6}$ & 604 & $101-102$ & 93 & orange \\
\hline $\mathrm{S}_{11}$ & $\mathrm{C}_{37} \mathrm{H}_{26} \mathrm{Cl}_{2} \mathrm{~N}_{4} \mathrm{O}_{6}$ & 693.5 & $97-98$ & 71 & brown \\
\hline $\mathrm{S}_{12}$ & & $\mathrm{C}_{39} \mathrm{H}_{32} \mathrm{~N}_{4} \mathrm{O}_{8}$ & 648 & $154-155$ & 95 & white \\
\hline
\end{tabular}

Table 2: Physical properties of compounds $\left(\mathrm{s}_{7-12}\right)$.

General procedure for the preparation Bis[(2-Aryl-6H-1,2dihydro-6-oxo[2,1-e](1,3) benzoxazine-1,1'-yl)]-2,4-diamidotoluene [21]

To a solution of (1.5 mmol) of Schiff bases $\left(\mathrm{S}_{1-6}\right)$ and $(2.5 \mathrm{mmol}$, $2.0 \mathrm{gm}$ ) of toluene diisocyanate in $1 \mathrm{ml}$ of Chloroform the reaction mixture was refluxed for $(3.0 \mathrm{~h})$. After the removal of the solvent under reduced pressure, the precipitate was washed with $2 \mathrm{ml}$ of $n$-hexane (three times) and filtered to remove any traces of toluene Diisocyanate. The final product was washed with $10 \% \mathrm{NaHCO}_{3}$ and water then dried. The physical properties of the synthesized compounds were illustrated in table 2 .

\section{Results and Discussion}

2-carboxy arylidine aniline $\left(s_{1-6}\right)$

These compounds were synthesized using similar procedure [20] and were characterized by IR as shown in table 3. The fol- lowing main absorption bands $\left(\mathrm{v}_{\max } \mathrm{cm}^{-1}\right)$ at (1585-1654) for $\mathrm{C}=\mathrm{N}$, (1402-1626) for $\mathrm{C}=\mathrm{C}, \mathrm{C}=\mathrm{C}$ Aromatic, (1619-1718) for $\mathrm{C}=\mathrm{O}$ while O-H appeared at (3328-3424) other stretching absorptions can be seen in the following Table. The NMR spectral data were indicated in table 4.

Bis[(2-Aryl-6H-1,2-dihydro-6-oxo[2,1-e](1,3) benzoxazine1,1'-yl)-2,4-diamidotoluene

These compounds were synthesized by cyclization of Schiff bases with toluene diiso cyanate using similar procedure ${ }^{(21)}$ and were characterized by IR and showed the following main absorption bands $\left(\mathrm{v}_{\max } \mathrm{cm}^{-1}\right)$ at (1216-1260) for C-N, (1023-115) for C-OC, (1446-1661) for $\mathrm{C}=\mathrm{C}, \mathrm{C}=\mathrm{C}$. (1661-1770) for $\mathrm{C}=\mathrm{O}$ While $\mathrm{N}-\mathrm{H}$ at (3248-3327) other band were shown in table 5 .

The NMR spectra were discussed in details as shown in the following table 6. 


\begin{tabular}{|c|c|c|c|c|c|c|}
\hline \multirow{2}{*}{$\begin{array}{c}\text { Comp. } \\
\text { No. }\end{array}$} & \multirow{2}{*}{ Ar. } & \multicolumn{5}{|c|}{ IR $v \mathrm{~cm}^{-1}$} \\
\hline & & $\mathrm{C}=\mathrm{C}$ Ar. & $\mathrm{C}=\mathrm{N}$ & $\mathrm{C}=\mathrm{O}$ & O-H & Others \\
\hline $\mathrm{S}_{1}$ & & 1402,1495 & 1588 & 1653 & 3369 & $\ldots \ldots . .$. \\
\hline $\mathrm{S}_{2}$ & & 1404,1579 & 1609 & 1651 & 3373 & $\ldots \ldots \ldots$ \\
\hline $\mathrm{S}_{3}$ & & 1464,1513 & 1585 & 1619 & 3424 & C-Cl/657 \\
\hline $\mathrm{S}_{4}$ & & 1496,1569 & 1623 & 1654 & 3372 & $\begin{array}{c}\mathrm{N}-\mathrm{O} \\
\text { sym/1311 } \\
\text { Assy/1443 }\end{array}$ \\
\hline $\mathrm{S}_{5}$ & & 1448,1573 & 1612 & 1663 & 3358 & $\ldots \ldots .$. \\
\hline $\mathrm{S}_{6}$ & & 1466,1626 & 1654 & 1718 & 3328 & C-0/1084 \\
\hline
\end{tabular}

Table 3: IR spectral data for compounds $\left({ }_{s 1-6}\right)$.

\begin{tabular}{|l|l|}
\hline Comp.No. & \multicolumn{1}{|c|}{} \\
\hline
\end{tabular}

Table 4: 1 HNMR data for compounds $\left(\mathrm{s}_{1-6}\right)$. 


\begin{tabular}{|c|c|c|c|c|c|c|c|}
\hline \multirow{2}{*}{$\begin{array}{c}\text { Comp. } \\
\text { No. }\end{array}$} & \multirow{2}{*}{ Ar. } & \multicolumn{6}{|c|}{ IR $v \mathrm{~cm}^{-1}$} \\
\hline & & $\mathrm{N}-\mathrm{H}$ & $\mathrm{C}=\mathrm{O}$ & C-O-C & C-N & $\mathrm{C}=\mathrm{C}$ Ar. & Others \\
\hline $\mathrm{S}_{7}$ & & 3327 & 1776 & 1023,1266 & 1260 & 1467,1573 & $\mathrm{C}-\mathrm{Br} / 635$ \\
\hline $\mathrm{S}_{8}$ & & 3282 & 1765 & 1062,1150 & 1266 & 1446,1603 & $\begin{array}{c}\mathrm{N}-\mathrm{O} \\
\text { sym/1380 } \\
\text { Assy/1526 }\end{array}$ \\
\hline $\mathrm{S}_{9}$ & & 3292 & 1767 & 1041,1154 & 1216 & 1447,1661 & $\ldots \ldots . .$. \\
\hline $\mathrm{S}_{10}$ & & 3267 & 1704 & 1071,1101 & 1219 & 1454,1495 & $\mathrm{C}-\mathrm{Cl} / 633$ \\
\hline $\mathrm{S}_{11}$ & & 3294 & 1661 & 1044,1145 & 1292 & 1448,1605 & ......... \\
\hline $\mathrm{S}_{12}$ & & 3248 & 1770 & 1029,1098 & 1239 & 1467,1610 & ......... \\
\hline
\end{tabular}

Table 5: IR spectral data for compounds $\left(\mathrm{S}_{7^{-}}{ }_{12}\right)$.

\begin{tabular}{|c|c|c|}
\hline Comp. No. & $\mathbf{R}$ & ${ }^{1}$ HNMR (PPM) DMSO-d6 \\
\hline $\mathrm{S}_{7}$ & & $2.47(\mathrm{~S}, 3 \mathrm{H}) \mathrm{CH} 3 ; 7.27-8.13(\mathrm{~m}, 18 \mathrm{H}, 5 \mathrm{Ar}-\mathrm{H}$ and $\mathrm{CH}), 7.8(\mathrm{~S}, 2 \mathrm{H}) 2 \mathrm{NH}$ \\
\hline $\mathrm{S}_{8}$ & & $2.34(\mathrm{~S}, 3 \mathrm{H}) \mathrm{CH} 3 ; 7.14-8.18(\mathrm{~m}, 19 \mathrm{H}, 5 \mathrm{Ar}-\mathrm{H}$ and $\mathrm{CH})$ \\
\hline $\mathrm{S}_{9}$ & & $2.22(\mathrm{~S}, 3 \mathrm{H}) \mathrm{CH} 3 ; 6.4-7.98(\mathrm{~m}, 17 \mathrm{H}) 3 \mathrm{Ar}-\mathrm{H}, 2$ furfuryl ring and $\mathrm{CH}) ; 7.74(\mathrm{~S}, 2 \mathrm{H}) \mathrm{NH}$ \\
\hline $\mathrm{S}_{10}$ & & $2.46(\mathrm{~S}, 3 \mathrm{H}) \mathrm{CH} 3 ; 7.14-7.74(\mathrm{~m}, 19 \mathrm{H}, 5 \mathrm{Ar}-\mathrm{H}$ and $\mathrm{CH}) ; 7.99(\mathrm{~S}, 2 \mathrm{H}) 2 \mathrm{NH}$ \\
\hline $\mathrm{S}_{11}$ & & $2.446(\mathrm{~S}, 3 \mathrm{H}) \mathrm{CH} 3 ; 3.77(\mathrm{~S}, 3 \mathrm{H})$ OCH3; 6.89-7.74 (m, 19H, 5Ar-H and CH); $7.98(\mathrm{~S}, 2 \mathrm{H}) 2 \mathrm{NH}$ \\
\hline $\mathrm{S}_{12}$ & & $2.54(\mathrm{~S}, 3 \mathrm{H}) \mathrm{CH} 3 ; 7.14-7.75(\mathrm{M}, 21 \mathrm{H}, 5 \mathrm{Ar}-\mathrm{H}$ and $\mathrm{CH}) 7.99(\mathrm{~S}, 2 \mathrm{H}) 2 \mathrm{NH}$ \\
\hline
\end{tabular}

Table 6: ${ }^{1} \mathrm{HNMR}$ data for compounds $\left(\mathrm{s}_{7-12}\right)$. 


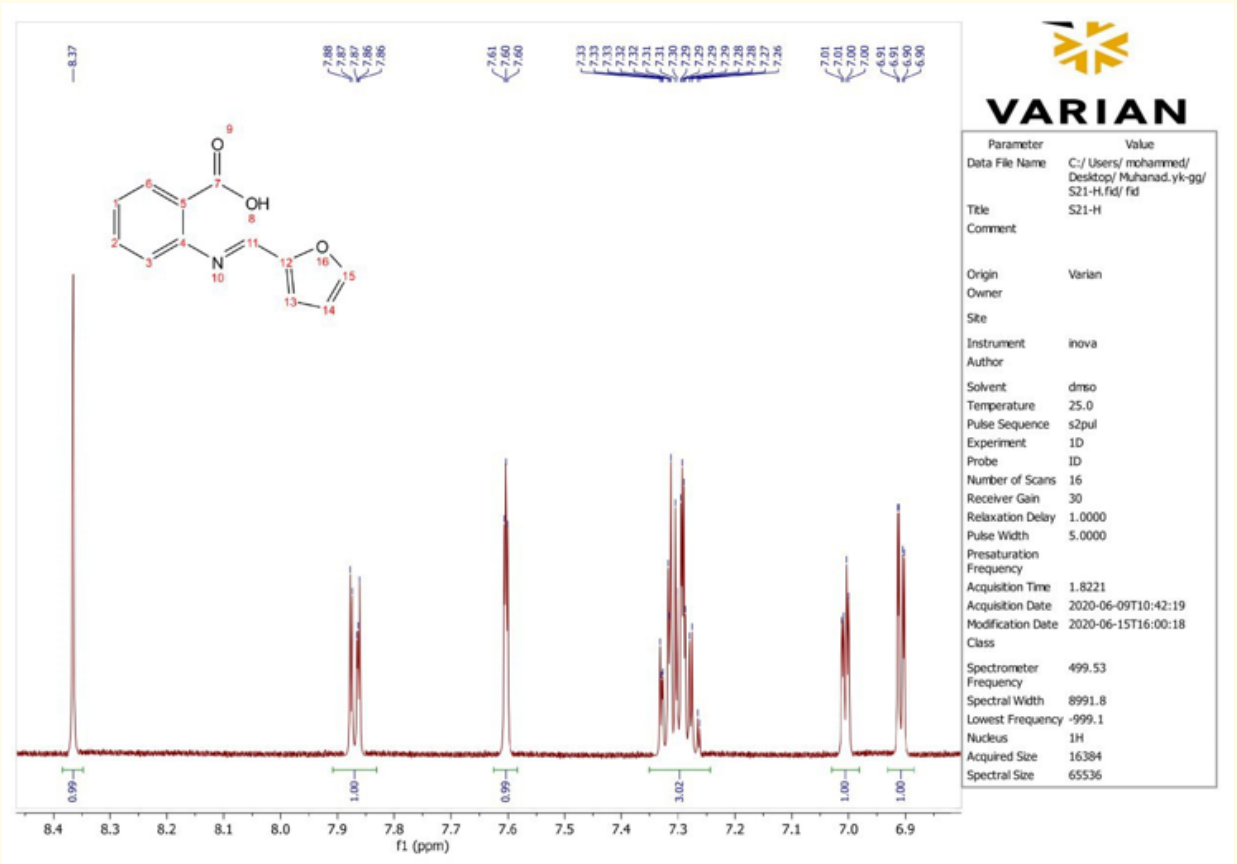

Figure 1: ${ }^{1} \mathrm{HNMR}$ of compound (S2).

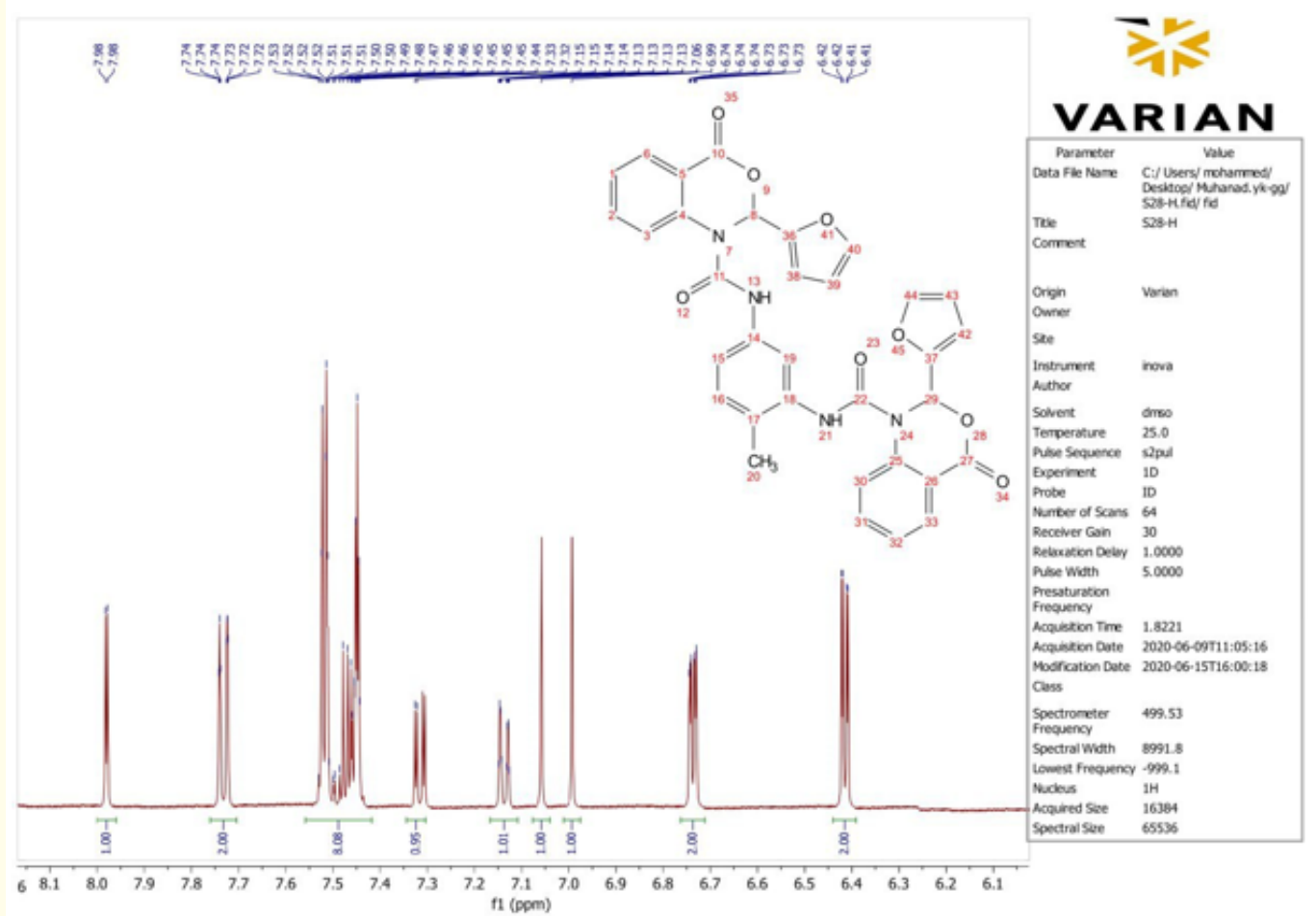

Figure 2: ${ }^{1} \mathrm{HNMR}$ of compound (S9) aromatic region. 


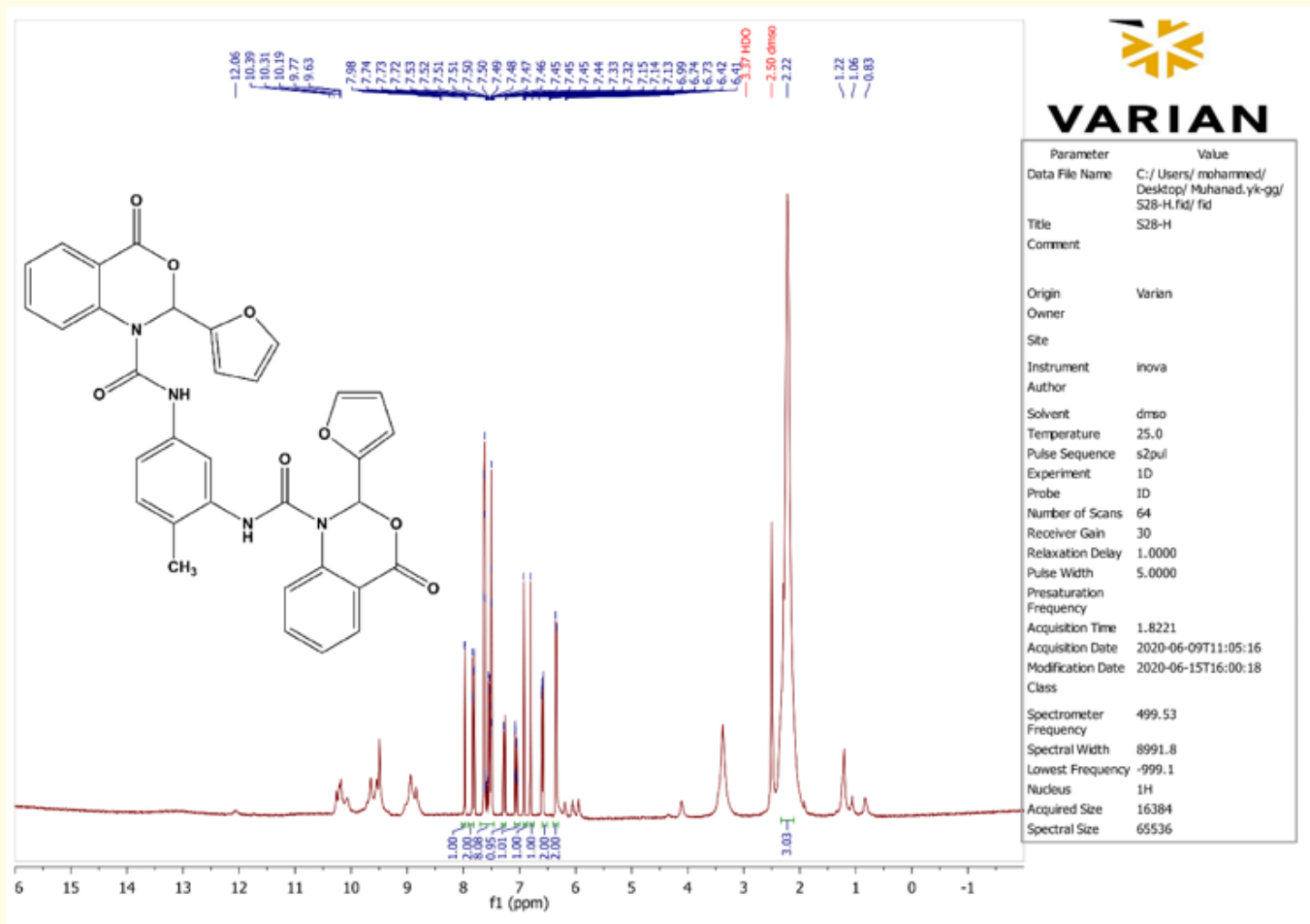

Figure 3: ${ }^{1} \mathrm{HNMR}$ of compound $\left(\mathrm{S}_{9}\right)$.

\section{Conclusion}

We conclude from the above study that Oxazine compounds were successively synthesized from the reaction of the corresponding schiff based of antharanalic acid schiff base with TDI according to the given spectral data. These compound will be studied for their biological activity based on our drug discovery program in our upcoming paper.

\section{Acknowledgement}

Authors would like to thank the ministry of higher Education and research for offering Ghufran the scholarship to do this work which is part of her $\mathrm{PhD}$ thesis.

\section{Bibliography}

1. MKML Rai., et al. "Synthesis of new series of 5, 6-dihydro$4 \mathrm{H}-1,2$-oxazines via hetero Diels-Alder reaction and evaluation of antimicrobial activity". European Journal of Medicinal Chemistry 44 (2009): 280-288.

2. MJ Elarfi and HA Al-Difar. "Synthesis of some heterocyclic compounds derived from chalcones". Scientific Review and Chemical Communications 2.2 (2012): 103-104.

3. V Tiwari., et al. "Novel oxazine skeletons as potential antiplasmodial active ingredients: Synthesis, in vitro and in vivo biology of some oxazine entities produced via cyclization of novel chalcone intermediates". Medicinal Chemistry 26.4 (2009): 4204-4206. 
4. BC Das., et al. "Design, synthesis and biological evaluation of 2H-benzo [b][1, 4] oxazine derivatives as hypoxia targeted compounds for cancer therapeutics". Bioorganic and Medicinal Chemistry Letters 19.15 (2009): 4204-4206.

5. D Zhou., et al. "Studies toward the discovery of the next generation of antidepressants. Part 5: 3,4-Dihydro-2H-benzo[1,4] oxazine derivatives with dual 5-HT1A receptor and serotonin transporter affinity". Bioorganic and Medicinal Chemistry Letters 16.5 (2006): 1338-1341.

6. S Wang., et al. "Novel hexacyclic camptothecin derivatives. Part 1: synthesis and cytotoxicity of camptothecin with A-ring fused 1,3-oxazine rin". Bioorganic and Medicinal Chemistry Letters 18.14 (2008): 4095-4097.

7. L Seal., et al. "An in vitro assessment of the antineoplastic potential of 2H-1, 3-0xazine-2, 6 (3H)-dione (3-oxauracil) a novel pyrimidine". Investigational New Drugs 15.4 (1997): 289-293.

8. Holly., et al. "Condensation products of aldehydes and ketones with o-aminobenzyl alcohol and o-hydroxybenzylamine". Journal of the American Chemical Society 66 (1994): 1875.

9. BP Mathew., et al. "An eco-friendly synthesis and antimicrobial activities of dihydro-2H-benzo- and naphtho-1,3-oxazine derivative". European Medicinal Chemistry 45 (2010): 15021507.

10. AK Verma., et al. "Silver-Catalyzed Domino Approach for the Synthesis of Benzoxazine/Oxazine-Fused Isoquinolines and Naphthyridines from o-Alkynyl Aldehydes". Journal of Organic Chemistry 78.13 (2013): 6657-6669.

11. SP Sakthinathan., et al. "Spectral correlations and antimicrobial activities of some (E)-N-Benzylidenepyridin-2-amines". International LETTERS OF Chemistry, Physics and Astronomy 6 (2013): 77-90.
12. MK Manjula., et al. "Synthesis of new series of 5,6-dihydro-4H-1,2-oxazines via hetero Diels-Alder reaction and evaluation of antimicrobial activity". European Journal of Medicinal Chemistry 44 (2009): 280-288.

13. X Wang., et al. "Influence of electronic effects from bridging groups on synthetic reaction and thermally activated polymerization of bisphenol-based benzoxazines". Journal of Polymer Science Part A: Polymer Chemistry 49 (2011): 1443-1452.

14. Z Brunovska., et al. "1, 3, 5-Triphenylhexahydro-1, 3, 5-triazine-active intermediate and precursor in the novel synthesis of benzoxazine monomers and oligomers". Macromolecular Chemistry and Physics 200 (1999): 1745-1752.

15. J Liu., et al. "Synthesis and surface properties of low surface free energy silane-functional polybenzoxazine films". Langmuir 29 (2013): 411-416.

16. WJ Burke., et al. "Condensation of Naphthols with Formaldehyde and Primary Amines". Journal of the American Chemical Society 74 (1952): 3601-3605.

17. WJ Burke., et al. "Bis-m-oxazines from Hydroquinon". Journal of Organic Chemistry 26 (1961): 4403-4407.

18. D Sicker and M Schulz. "Benzoxazinones in plants: occurrence, synthetic access, and biological activity". Studies in Natural Products Chemistry 27 (2002): 185-232.

19. P Zhang., et al. "Potent nonsteroidal progesterone receptor agonists: synthesis and SAR study of 6-aryl benzoxazines". Bioorganic and Medicinal Chemistry Letters 12 (2002): 787-790.

20. Hammet IP. Physical organic chemistry'Mc Graw-Hill Bokk Co. Ink. New York (1940). 
21. S Irani and F Nikpour. "An Efficient Approach for the synthesis of N-Phenyl carboxmaido-2-aryl-1,2-dihydro (4H)-3,1-benzoxazine-4-one". Journal of the Iranian Chemical Society 7.4 (2010): 859-863.

\section{Assets from publication with us}

- Prompt Acknowledgement after receiving the article

- Thorough Double blinded peer review

- Rapid Publication

- Issue of Publication Certificate

- High visibility of your Published work

Website: $\underline{w w w}$.actascientific.com/

Submit Article: www.actascientific.com/submission.php Email us: editor@actascientific.com

Contact us: +919182824667 